\title{
Application Research of Mooc in Flipped Classroom of College Courses Zhongbin $\mathrm{Wei}^{1, \mathrm{a}^{*} \text {, Song Zhao }}{ }^{2, \mathrm{~b}}$ and $\mathrm{Kun} \mathrm{Wu}^{3, \mathrm{c}}$ \\ Mechanical and electrical technology department, Xijing University, Xi'an, China \\ a $358825406 @ q q . c o m,{ }^{b} 610633400 @ q q . c o m,{ }^{c} 342752260 @ q q . c o m$
}

\section{Keywords: MOOC; College courses; Flipped classroom; Teaching mode}

\begin{abstract}
Based on MOOC, the teaching mode of flipped classroom in the university, help to improve the quality of university learning, realize the purpose and function of university study, provide experience for the reform of other courses. Mainly from four aspects of the teaching procedure, teaching strategy, quality evaluation and guarantee factors to build the flipped classroom teaching mode based on MOOC.
\end{abstract}

\section{What is MOOC}

Short for MOOC is the Massive Open Online Course, namely the large scale network Open courses. MOOC in the current information technology background, has its unique advantages.

MOOC characteristics has the following courses:

(1)the tool resources diversification: MOOC curriculum integration of a variety of social networking tools and various forms of digital resources, form a diversified learning tools and rich curriculum resources.

(2)course is easy to use: break through the limitation of traditional course of time, space, learners can learn at home rely on the Internet all over the world famous universities at home and abroad.

(3)course re-description: break through the traditional limit enrollment, learners can satisfy the large-scale courses.

(4)courses in autonomy: MOOC course has high enrollment rate, but also has high dropout rate, which requires the learner with strong independent learning ability to finish the course content.

\section{Value analysis based on Mooc in flipped classroom}

Flipped classroom is the teaching model of the common concerns for education workers all over the world, is also longed for the forefront of education concept shadow with MOOC. At present, most of the education with flipped classroom in China stay at practice and research stage based on the micro classroom[1].

MOOC focus on learners' autonomous learning. For example, focus on learners' interaction between each other, learning time, place, learning progress, etc without special requirement, and so on. However, if only by the students to participate in the MOOC study, there are some unavoidable disadvantages. Learners are difficult to stick to it, for example, MOOC registered person many, who rarely; When learners have confused guidance teacher to make a quick tutorial and answering questions and so on. And the flipped classroom teaching mode is a kind of traditional classroom teaching and video before class learning activities, to achieve the status of students as the center of new teaching mode[2]. Based on MOOC university study with flipped classroom teaching model, which using the MOOC before classroom such as video and online evaluation of teaching and the classroom teaching, such as teachers' leading and answering questions in the classroom, students' interaction and display, etc. So the combination of teaching can fully carry forward the "long" MOOC, avoid the "short", to improve the quality of university learning.

MOOC emerged as a newly emerging things in the field of education, different scholars to research the depth and breadth of its are very different. The further study of MOOC should consider the following content. (1) about the MOOC learning design. Different forms of learning, MOOC how to help learners to improve learning effect, MOOC can adopt what kind of teaching design or technical support for learners to provide a more effective learning experience are to be further 
discussed. (2) research on the profit pattern of MOOC. Professor offer free MOOC spend a lot of time and effort, teachers offer continuous power come from? MOOC the development, maintenance, guiding, operations, such as high costs borne by the who, the sustainable development of the need to find a real business model. (3) about the MOOC education theory and education method. Three courses in the platform close to the traditional classroom teaching form, whether MOOC itself has the unique teaching mode and teaching method. (4) learning experience, the study of MOOC. Higher education in the future how to better serve the society, what kind of students, subject, learning environment, learning content is effective to adopt MOOC form, MOOC learners' learning motivation and learning what are the differences in performance influence factors. (5) about the negative impact of MOOC research. Now most people are recognized for MOOC or neutral, but its negative effect about the existence of education field, what are these negative effects, the researchers can try to make in-depth research of interest.

In the traditional teaching model, the knowledge mainly teaching by teachers in the classroom, and knowledge is mastered by students which need students by practice operation, homework. And the traditional teaching mode is subverted by flipped classroom teaching mode, the knowledge done through outside the classroom by watching online videos, knowledge mastered through the guidance of the teacher in the classroom as well as the interaction between students and teachers to complete. In flipped classroom teaching mode, the role of teachers and students there has been a fundamental shift, truly achieve the form of learning settled teaching, the real implementation is given priority to with students, give priority to with students' learning[3]. Flipped classroom teaching process through the change makes the class time to redistribute and leave more time for students, really realized the master class status for students. In the university learning, based on MOOC with flipped classroom teaching mode, stimulate students' learning enthusiasm and initiative, lead the students to form a new university study, learning objectives, establish a new university to set up university planning, adjustment learning psychology, flexible use of university learning methods, guide students to better transition from high school to university, for the university study and lay a solid foundation for future development.

University study with flipped classroom teaching mode based on MOOC which the effect is good[4]. So the further analyze and demonstrate its universality, will be gradually extended to other courses based on the MOOC in flipped classroom teaching mode reform. The implementation of flipped classroom for other courses teaching mode reform to provide experience and reference, better to improving the quality of higher education, to promote students' learning and development. In addition, based on the MOOC university study the implementation of the flipped classroom teaching mode, also help to promote the information environment in the reform of teaching methods, means and contents.

\section{Research on Flipped Classroom Teaching Mode Based on the MOOC Practical Exploration}

\section{(1) Teaching procedure}

Before class activities: teacher's before class activities mainly involves the analysis of the teaching goal of the course, and the existing curriculum MOOC teaching video, to adjust the small test, complement and release. The class activities of students, mainly according to problems purposefully for learning MOOC video, and complete the relevant tests in the MOOC video.

In the classroom activities: on the one hand, according to the students in the learning MOOC with the common problems, the teacher will coach and answer questions; on the other hand, by discussing between teachers and students, process and master knowledge; Finally, the students show results and share experiences.

After classroom activities: Its mainly teachers further to guide students to deepen the learning content, and to carry out the leak fill a vacancy, sometimes students explore independently, finish the homework.

(2)Teaching strategy

The basic concept of teaching strategy is "teaching way is according to the way of the study", "give full play to teachers' leading role", "the students is the master of study[5], stimulate students' 
autonomous learning, actively participate in learning", and so on.

On the concrete methods mainly include: teachers guide students to study teaching video strategy, the strategy of students learning MOOC teaching video before class, students participate in MOOC platform to discuss and complete the quiz, classroom interaction and discussion, supplemented by teaching strategies, teachers according to students' learning situation in a timely manner to adjust teaching strategies, and so on.

\section{Quality evaluation}

Based on MOOC the flipped classroom teaching model of curriculum quality evaluation mainly includes three parts: firstly, university learning curriculum MOOC before class teaching quality evaluation of video which based on the platform automatically generated data, including the number of students learning video and practice, participation, discussion and number, to complete the quiz, and so on. Secondly, the classroom learning quality evaluation, based on the student's performance in the classroom, including students participate in class discussion, interaction between students and teachers, students learning outcomes show case, etc. Thirdly, the evaluation of quality courses, which could prove the degree of completion of the course students, in addition to including two aspects mentioned above, also includes the use of summative evaluation to detect or essay form students mastery of curriculum knowledge and use of degree, using standard scoring system on students' academic level[6].

\section{Security factors}

Based on MOOC, the security factors of flipped classroom teaching pattern in university, mainly including work and rest time is flexible, provides the corresponding network platform and information technology support, teachers' role change, improve students' autonomous learning ability, information literacy and adjust the relevant teaching management system, reform learning achievement evaluation methods and so on.

\section{Conclusion}

Throughout the domestic and oversea foreign research and practice, the current research based on MOOC in flipped classroom practice should be explored and clarified the following issues: (1) the relationship between MOOC, the flipped classroom and the students' autonomous learning; (2) the relationship between MOOC, the flipped classroom learning efficiency and the students' age; (3) the relationship between the maximum benefits of flipped classroom and classroom teaching based on MOOC; (4) the relationship between the teacher role transformation and a number of teachers in a classroom; (5) the negative effects problems of online learning; (6) the relationship between promote MOOC, flipped classroom and reform the other education factors; (7) the relationship between promote flipped classroom based on MOOC, social, communities, families and schools together education and so on[7].

Based on MOOC, the flipped classroom effectively show the education idea about the core of students. The students realized from passive, rely on, unified, virtual and identity" of the traditional learning style change to active, independent, distinctive, experience and problems of the modern study way. Students' understanding of knowledge is deeper than before, has realized new responsibility in the job and classroom tasks, experiment and test. Based on MOOC, the flipped classroom is conducive to cultivate and enhance students' innovation ability, independent thinking ability, learning ability and the ability to execute. This model could be copied to any classroom, and don't need more money[8].

\section{Acknowledgments}

The work in this article is supported by scientific research fund of Xijing university (No. XJ160117) 


\section{References}

[1] Yi Qinghong: The Flipped Classroom and Its Structure Based on MOOC, Modern Educational Technology, Vol. 25(2015)No.4,p94-100.

[2] Wang Xanghong: Based on the MOOC university study guides with flipped classroom teaching mode of value and construction,Science and Technology, Vol.13(2017), p.333.

[3] B.C.Ji: Our Country's Higher Education Scale Forecast Analysis in 2020, Vol. 1 (2011) No. 1, p. 305.

[4] J.L.Zhang:Introducing a New Teaching Model: Flipped Classroom,Journal of Distance Education, Vol.3(2015), p.46-51.

[5] W.X.Cai, J.Wang: The First Year of MOOC, Vol.4(2012),P.16-18.

[6] J.B.Wang, H.T.Yang: Research of Flipped Classroom Teaching Model Based on MOOC, China audio-visual education, Vol.336(2015), p.102-108.

[7] Y.K.Chen,L.A.Tian: Introduction to MOOC and Flipped classroom, (2014), p.30-33.

[8] Jonathan bergmann, Aaron Sam: The flipped classroom and MOOC for teaching(Translation by Song Yi 2015). 